\title{
RETRIBUTION, RESPONSIBILITY AND FREEDOM: THE FALLACY OF MODERN CRIMINAL LAW FROM A BIBLICAL-CHRISTIAN PERSPECTIVE
}

\author{
E. L. (Stacey) Hebden Taylor* \\ The Positivistic and Scientistic Attack Upon the \\ American Penal System
}

Of all the social movements in American society during the past hundred years, none threatens our future as free men and women under God more than the attempt to adjust the American legal, criminal and penal system to fit the modern positivist, scientific and secular humanist theory of the human person-an attempt to substitute medicine for morals as the basis of American criminal law. Medical "principles" are today subverting the basic principles of the American criminal justice system.

Whereas a hundred years ago the expert in mental medicine claimed to be able to deal with violent or deluded patients, or with those who were unmanageably hysterical, depressed to the point of total incapacity or senile to the point of infantalism, now the psychiatrist and the social worker ask to apply their therapeutic model of the criminal and the deviant, as a legal right to "treat," "reform," and "rehabilitate" any perpetrator of crime."

This therapeutic ideology of crime control and treatment rests upon the implicit assumption that crime is a medical issue rather than a matter of legality and morality. The law-breaker, it is claimed, is suffering from a disease of the mind; he or she is therefore to be cured rather than punished, and the treatment is to be determined according to the expertise of modern medical and psychiatric treatment.

Due to insidious propaganda in the universities, in the mass media and even in the liberal modernist pulpits of our country, millions of people who a hundred years ago would have had the honesty to admit that they were sinful, disobedient, unfaithful or wicked, as the case might be, now claim that the reason they behaved as badly as they did is because they are "sick" and in need of treatment by medical rather than moral or perhaps penal methods. ${ }^{2}$

Superficially considered, this change in attitude has been acclaimed as a step in the direction of greater humanitarianism and progress. In actual fact, as I shall hope to prove in this paper, it can only be explained as the expression of the steady

Copyright (c) 1981 by Duke University.

* Professor of Sociology, Dordt College.

1. E. Johnson, Crime, Correction, and Society 188-190, 494-504 (3rd ed. 1974).

2. E. Berne, Transactional analysis in Psychotherapy: A Systematic Individual and Social Psychiatry (1961); W. Glasser, Reality Therapy: A New Approach to Psychiatry (1965); E. Glover, Roots of Crime 117-169 (1960). 
encroachment by secular humanist social science upon territory occupied until recently by biblical morality and by the Christian view of the individual as a person created in God's image and as a sinner in need of redemption.

Instead of repenting of his sins, the modern American supposes that he can now be redeemed by the application of group therapy, sensitivity training and psychoanalysis to his "problem" and even by the use of tranquilizers and drugschemical equivalents of grace. ${ }^{3}$ In many respects the new struggle taking place between the rival empires of positivistic, scientistic social science and Christian legality and morality based upon the Holy Scriptures seems to be the contemporary equivalent of the nineteenth century battle between Darwinian and biblical explanations of man's origin, nature and destiny. ${ }^{4}$

True, the modern war is much more politely conducted than was that which agitated our Victorian great-grandparents. Indeed, it is so decorous that it is not recognized by many American Christians as being a battle at all. But the issues are similar and the consequences will be just as serious for American criminal justice as they were for the exploitation of the poor in "the struggle for survival" and in the justification of racism. Hofstadter's demonstration ${ }^{5}$ of those consequences should be read by every American judge and lawyer before accepting the therapeutic model, based as it is upon evolutionary humanistic presuppositions. Thus, psychiatrists, social scientists, lawyers and judges since Darwin, Freud and Pavlov have been busy doing for man's morals, politics, criminology and penology what Charles Darwin and Thomas Huxley tried to do for his pedigree. ${ }^{6}$

According to the view of man as the product of evolution, heredity and environment, criminals must not be held responsible for their misdeeds because they are psychologically sick or sociologically maladjusted rather than morally sinful. As expressed by Edward Glover, co-founder of the Institute for the Study and Treatment of Delinquency in London:

When the social historian of the future looks back to the first half of the 20th century it will by then be apparent that amongst the revolutionary changes to be credited to that period, two at least were of vital importance to the development of humanism; the liberation of psychology from the fetters of a conscious rationalism; and the subsequent emancipation of sociology from the more primitive superstitions and moralistic conceptions of crime. ${ }^{7}$

Glover dismisses such uniquely human reactions as having a guilty conscience after wrongdoing as the expression of unconscious fixations imposed by the human ape's "super-ego" upon his animal "ego" and "id." Instead of having been created in God's image and therefore endowed with a sense of responsibility to their

3. R. Fieve, Moodswing: The Third Revolution in Psychiatry 119-66 (1976).

4. E. Taylor, Evolution and the Reformation of Biology: A Study of the Biological Thought of Herman Dooyeweerd . . . and J. J. Duyveene de WIT 42-54 (1967); L. Gilkey, Maker of Heaven and Earth, Ch. 5 (1965).

5. R. Hofstadter, Social Darwinism in American Thought, 1860-1915 (1945).

6. Id; R. Nisbet, Social Change and History: Aspects of the Western Theory of DevelopMENT 159-188 (1969).

7. Glover, supra note 2, at ix. 
creator for their actions, human beings are really only the product of animal heredity acting upon their physical and social environment. ${ }^{8}$

The therapeutic ideology is premised on an equation between the causes and cures of mental and physical illnesses. Once it is admitted that the human mind can be sick just as the body can be, we must expect those who suffer from mental illness of whatever degree to make the same claim to be relieved of personal responsibility for their actions as do those persons whose incapacity is obviously due to purely physical symptoms. Illness, of course, must be treated by medical science- unlike moral failure, for which other measures are appropriate: personal effort and repentance on the part of the sinner himself, perhaps accompanied by exhortation, or punishment administered by parent, teacher, magistrate, minister or friend. And so secular humanist evolutionary scientism, having supposedly defeated the Word of God over the riddles of the universe, now seeks to usurp the role of biblical morality and law in deciding how we should conduct our lives, organize our criminal justice system, and "treat" rather than punish our "maladjusted" citizens who break the criminal law. This process has been ably demonstrated by that bete noire of the psychiatric profession, Thomas Szasz, in his numerous books exposing the pretensions of his fellow American psychiatrists and taking a hard look at the actual roles played by psychiatrists, including The Myth of Mental Illness, ${ }^{9}$ Law, Liberty and Psychiatry, ${ }^{10}$ Psychiatric Justice ${ }^{11}$ and The Theology of Medicine. ${ }^{12}$

As a result of this new psychological paradigm, Congress and State legislatures are being lobbied by organizations such as The American Correctional Association, the National Association of Social Workers, and psychiatric and psychological associations. The objective of these various pressure groups is to introduce a completely new penal system, based upon medical and non-biblical models of man, rather than upon the religious doctrine of man and woman as persons created in God's image, responsible to $\mathrm{Him}$ for their conduct in this life. ${ }^{13}$

Such a substitution of medicine for biblical morality as the basis of our present American criminal justice system and criminal law will involve, when carried to its ultimate end, nothing less than a fundamental revolution in the existing conception and structure of Anglo-American law. That revolution presents a bleak pic-

8. Id., at 292-324, Recent Advances in the Psycho-Analytical Study of Delinquency and PsychoAnalysis and Criminology.

9. T. Szasz, The Myth of Mental Illness: Foundations of a Theory of Personal Conduct (1961).

10. T. Szasz, Law, Liberty and Psychiatry: An Inquiry into the Social Uses of Mental Health Practices (1963)

11. T. Szasz, Psychiatric Justice 74-82 (1965).

12. T. Szasz, The Theology of Medicine: The Political-Philosophical Foundations of MediCal Ethics (1976); T. Szasz, Ideology and Insanity, Essays on The Psychiatric Dehumanization of MAN (1970).

13. For well-balanced explanations of the Christian doctrine of $\sin$ and individual responsibility see: E. Brunner, Man in Revolt, A Christian Anthropology 215-36 (tr. O. Wyon, 1947); G. Berkouwer, Man: The Image of God (tr. D. Jellema, 1962); G. Berkouwer, Sin (tr. P. Holtrop, 1971); and H. FARMER, GOD AND MEN 70-95 (1947). 
ture: totalitarian enslavement of the whole population by social conditioners and planners. This enslavement was graphically portrayed by C. S. Lewis in his lectures, The Abolition of Man, ${ }^{14}$ and in his novel, That Hideous Strength, ${ }^{15}$ as well as by George Orwell in Nineteen Eighty-Four, ${ }^{16}$ by David Karp in the frightening novel One ${ }^{17}$ and by Nicholas $\mathrm{N}$. Kittrie in The Right to be Different. ${ }^{18}$

\section{II}

\section{The Christian Understanding of Retributive Justice and RESPONSIBILITY}

Up until recently, the main function of criminal courts in the English-speaking world has been to determine whether or not persons accused of crime actually committed the act in question. Psychological considerations such as motive are taken into account when they have a bearing upon the probability or improbability of guilt or in murder cases, in which insanity can be pleaded. The American criminal justice system is based upon and derived from four implicit, if not explicit, assumptions: ${ }^{19}$

(1) Everyone, except children under legal age and lunatics, knows the difference between right and wrong. Due to the operation of God's temporal conserving or "common grace" upon our consciences, we can tell the difference between acts of right and acts of wrongdoing. ${ }^{20}$

(2) Everyone, apart from children and lunatics, is able to choose between doing right and doing wrong. According to the word of Christ, man is not merely the product of his heredity acting upon his environment. Man's personality or "heart" is the product of the response he makes to his creator as well as to his heredity and environment:

Nothing that goes into a man from the outside can defile him; no, it is the things that come out of him that defile a man. . . For from inside out of a man's heart come evil thoughts, acts of fornicating, of theft, murder, adultery, ruthless greed, and malice, fraud, indecency, envy, slander, arrogance and folly; these evil things all come from the inside and they defile the man. ${ }^{21}$

Of course no Christian wishes to deny the hindrances to man's freedom caused by both original and personal sinfulness and by centuries of accumulating social sin expressed in the sinful structures of society, including its criminal justice system and laws; but the power of these influences to prevent freedom of choice is found

14. C. Lewis, The Abolition of Man; or, Reflections on Education with Special Reference to the Teaching of English in the Upper Forms of Schools (1947).

15. C. Lewis, That Hideous Strength, A Modern Fairy-Tale for Grown-Ups (1946).

16. G. Orwell, Nineteen Eighty-Four, A Novel (1949).

17. D. Karp, One, A Novel (1954).

18. N. Kittrie, The Right to be Different; Deviance and Enforced Therapy $340-71$ (1971).

19. These assumptions are discussed by N. Micklem in his lectures at Oxford University, LAW AND the Laws 1-21 (1952) and explained in my own work, The Christian Philosophy of Law Politics and the State: A Study of the Political and legal Thought of Herman Dooyeweerd . . 278-358 (ch. VII, The Christian Philosophy of Law) (1966).

20. Bavinck, Calvin and Common Grace, in Calvix and the Reformation: Folr Stldies 99 (W. Armstrong ed. 1909).

21. Mark 7:14 ff. (New English Bible). 
only among the insane. Upon this issue of individual responsibility for wrongdoing, orthodox Christians are bound to take issue with the theories of many secular social scientists, who contend that people are products of sex urges, repressions, inhibitions and fixations stripped of free choice. ${ }^{22}$

(3) Anyone who chooses to do wrong should be properly punished for it; but the State may only punish people for the outward acts of crime they commit and not for all the sins for which they may be guilty, nor for their inward sinful thoughts. Punishment is the price we pay for our freedom to choose evil deeds over good deeds.

Such a doctrine of individual responsibility for one's conduct has not only curbed the arbitrariness of the executive branches of American and British states but it has also restrained the follies of each individual citizen. Each of us, from the Queen and President down to the humblest village policeman and peasant, is held responsible to God's higher moral law. In his classic work on The Law of the Constitution, A. V. Dicey pointed out that no one in Britian [and we might add in the United States] is allowed to plead in his defense for any unlawful act "that he did it under the orders of a master or superior. . . [T]his doctrine of individual responsibility is the real foundation of the legal dogma that the orders of the King himself are no justification for the commission of a wrongful or illegal act." 23

That God is indeed the source of our political and legal obligations is proved daily by the oaths taken upon the Bible in all American and British courts "to tell the truth and nothing but the truth so help me God." No person may hold office under the President without first taking an oath upon the Bible to uphold the Constitution.

(4) Our Founding Fathers claimed that they had established a "rule of laws" rather than the "rule of men." Disputing the positivistic notion that the Constitution rests merely upon the will of the majority, Corwin pointed out that "The attribution of supremacy to the Constitution on the ground solely of its rootage in popular will represents ... a comparatively late growth. . . Earlier the supremacy accorded to constitutions was ascribed less to their putative source than to their supposed content, to their embodiment of an essential and unchanging justice."24

Our Anglo-American legal tradition insists upon the rule of law. The field of the criminal law implies a combination of the notion of the equality of all citizens before the law with the notion that the police powers of the state must be rigidly defined. The rule of law in this sense is expressed in the maxim, Nulla poena sine lege (no penality without law). In our legal tradition the rule of law includes at least four basic concepts: (1) First, it means that the category of crimes should be determined by general rules of a more or less fixed character; (2) It implies that

22. Campbell, On the Conflicts Between Biological and Social Evolution and Between Psychology and Moral Tradition, $30 \mathrm{Am}$. Psychologist 1103 (1975). For evidence of this tendency, see also O. Mowrer, ThE Crisis in Psychiatry and Religion 47-55 (1961) and P. Vitz, Psychology as Religion (1977).

23. A Dicey, Introduction to the Study of The Law of the Constitution 207 (8th ed. 1931). Cf. R. Rushdoony. This Independent Republic: Studies in the Nature and Meaning of American History 146-151 (1964).

24. E. Corwin, The "Higher" Law Background of American Constitutional Law 4-5 (1928). 
no one should be punished except for a crime which falls within these general rules; (3) The rule of law means that penal statutes should be strictly construed so that no act is made criminal which is not clearly covered by the statutes; and (4) Penal laws should never have retrospective or retroactive effect.

It may be noted in passing that Anglo-American law does not entirely satisfy these rigorous rules. The category of crimes is determined by general rules, though this does not prevent Congress or Parliament from making special exceptions if it wishes to do so; nor does it prevent these legislative bodies from delegating the power of making new crimes. Yet all such legislation is exceptional and it is the general tendency or spirit of the law and its administration which matters. Our best jurists and lawyers would repudiate, and would arouse a vast public outcry against themselves if they tried to enact a rule such as that enshrined in the German law of June 28, 1935, which stated:

Any person who commits an act which the law declares to be punishable or which is deserving of penalty according to the fundamental conceptions of a penal law and sound popular feeling shall be punished. If there is no penal law directly covering such an act it shall be punished under the law of which the fundamental conception applies most nearly to the said act. ${ }^{25}$

(5) A further assumption upon which our criminal justice system has been based is the principle of retributive justice. Briefly stated, this says that no one should be punished unless in actual fact he or she has committed some definite crime defined by the criminal law. This principle of retributive justice requires punishment to be tied to guilt and wrongdoing. Thus guilt is a necessary condition of punishment. Strictly speaking, one cannot be punished for something one has not done, though one may be made to suffer unjustly for it.

Philosophers and theologians as well as jurists have often discussed how far punishment is a deterrent, how far it is disciplinary or reformative, and whether it should be retributive in character. On this question I can only say that punishment is not defensible morally as a deterrent since it would then mean using a person as a means to some socially useful end. Punishment can only be justified as the expiation, atonement and satisfaction for a guilty mind (mens rea).

In his essay The Humanitarian Theory of Punishment, C. S. Lewis writes of this deterrent aspect of punishment as follows:

If we turn from the curative to the deterrent justification of punishment we shall find the new theory even more alarming. When you punish a man to make of him an "example" to others, you are admittedly using him as a means to an end; someone else's end. This, in itself, would be a very wicked thing to do. On the classical theory of punishment it was of course justified on the ground that the man deserved it. That was assumed to be established before any question of "making him an example" arose. You then, as the saying is, killed two birds with one stone; in the process of giving him what he deserved you set an example to others. But take away desert and the whole morality of the punishment disappears. Why, in heaven's name, am I to be sacrificed to the good of society in this way-unless, of course, I deserve it? ? $^{26}$

25. Quoted in Hall, Nulla poena sine lege, 47 YALE L. J. 165 (1937).

26. C. Lewis, The Humanitarian Theory of Punishment, in Essays on The Death Penalty 1, 6-7 (T. Ingram ed. 1963). 
If one rules out the idea of just desert and retribution for wrongdoing and leaves only deterrence as a valid ground for punishment or "treatment," there is no reason whatsoever why one should confine oneself to inflicting pain or punishment or even treatment upon the actual doer of the wrong deed; why one should not, for example, inflict pain upon the wrongdoer's wife and children. That might well serve as the best deterrent of all, as the Nazis and Communists proved when they confined a man's loved ones in concentration camps. Yet such a proposal has only to be suggested in English-speaking lands to excite a cry of horror and moral outrage. But why? The answer is, because it would be hard if not downright unfair and unjust that those who had done nothing wrong should be made to suffer. Such an answer implies that the connection between wrong conduct and suffering must exist, in order to make us acquiesce in the deterrence.

Imprisonment, whether it be called punishment or treatment, is not likely to be remedial or reformative unless it is recognized by the person being punished or "treated" as being just, and therefore retributive or deserved. In this connection it is encouraging for me to note, as a Christian sociologist teaching a course in criminology and penology, a return to this biblical justification of punishment in terms of retributive justice in the new "re-thinking school" in the works of Wilson, ${ }^{27}$ van den Haag, ${ }^{28}$ and Berns. ${ }^{29}$

To think of either punishment or treatment merely in terms of deterrence is surely to make complete nonsense of the first principles of natural justice and biblical law. ${ }^{30}$ By using such a mundane yardstick as utility and making that the crux of their position in the debate over capital punishment, the abolitionists have in fact reduced justice to a branch of statistics and mathematics. That deterrence has, in fact, become the chief consideration in the modern discussion of punishment is really only a measure of how debased contemporary American and British ideas of law have become today.

\section{The Characteristics of the Therapeutic State}

The advocates of the therapeutic model say that the old retributive doctrine is barbaric, demeaning and degrading to criminals. This view found expression in the new concept of insanity introduced to American thinking about criminal law by Judge Bazelon's decision in the Durham case. ${ }^{31}$ The Durham rule held that "an accused is not criminally responsible if his unlawful act was the product of mental disease or mental defect." 32 The former preoccupation with the distinction between

27. J. Wilson, Thinking about Crime 205-221 (1975), a discussion of the retributive basis of capital punishment in particular and punishment in general.

28. E. van den Haag, Punishing Criminals: Concerning a Very Old and Painful Question 8-23 (1975).

29. W. Berns, For Capital Punishment: Crime and the Morality of the Death Penalty 128-52 (1979).

30. F. Zimring, Perspectives on Deterrence (1971); J. Andenaes, Punishment and Deterrence (1974).

31. Durham v. United States, 214 F.2d 862 (D.C.Cir. 1954)

32. Id., at 874-75. 
right and wrong conduct of the M'Naghten Rule was discarded in Durham for a new test of criminal responsibility. In the view of Judge Bazelon, a fervent disciple of secular humanist psychiatry, "our collective conscience does not allow punishment where it cannot impose blame."33 Criticizing this new doctrine of legal irresponsibility Szasz writes:

The Durham decision . . resulted in a host of specific difficulties. Perhaps the most fundamental problem is the idea that, to be "punished" as a lawbreaker, a person must be blameworthy. If we accept this, we must determine whether, and in what measure, an offender can be blamed. To complicate matters further, the Durham decision has created a firm but vague connection between blame-worthiness and mental health; it insinuated the proposition that only mentally healthy persons can be blamed for what they do. This presumption has created a moral and scientific vacuum, into which the forensic psychiatrist has eagerly projected himself. . . The Durham decision . . . reifies some of the shakiest and most controversial aspects of contemporary psychiatry-that is, the definition of mental disease. . . and by legal fiat seeks to transform inadequate theory into judicial fact. . . Clearly, the Durham decision represents the culmination of what could aptly be called the psychiatrization of the criminal law. ${ }^{34}$

Szasz was but one prophetic voice among the numerous critics who assailed the Durham decision before its ultimate demise in the D.C. Circuit with United States $v$. Brawner. ${ }^{35}$ Judges in other circuits were not hesitant to spell out the weaknesses in Durham: the rule "raised near-impossible problems of causation"; it failed "to give the fact-finder any standard by which to measure the competency of the accused"; "psychiatrists . . . in effect usurped the jury's function."36

The M'Naghten Rule, still in use in some form in about 35 jurisdictions, has also been threatened with transformation, since the insanity defense represents an insoluble conflict between deterministic theories of crime causation and the persistent classical free-will theory of moral responsibility, which is related to mens rea. The various tests of insanity, including the recent Model Penal Code of the American Law Institute, cannot resolve the issue. The controversy over just where mental health ends and crime begins continues. Criminal law prescribes punishment while still recognizing mitigating mental circumstances in some cases. Treating a criminal offense strictly as a health problem may jeopardize the legal safeguards inherent in the idea that moral responsibility is necessary to determine guilt. In addition, the medicalization of crime often conceals the fact that crime is a conflict between those who make and enforce the laws and those who violate them. Further, the insanity defense touches on questions of basic social beliefs in its application to specific cases, in that it seeks to make a distinction between those who are morally

33. Id., at 876 .

34. SzAsz, supra note 10 , at 132.

35. 471 F.2d 969 (D.C. Cir. 1972).

36. United States v. Freeman, 357 F.2d 606, 621-22 (2d Cir. 1966). Judge Kaufman concluded that the Durham rule was inadequate: "It seems clear that a test which permits all to stand or fall upon the labels or classifications employed by testifying psychiatrists hardly affords the court the opportunity to perform its function of rendering an independent legal or social judgment." Id. See also R. ARENS, INSANITY DEFENSE 67-75 (1974), on the role of the psychiatrist in Durham rule cases; and Judge Bazelon's post-mortem on Durham in New Gods for Old: "Efficient" Courts in a Democratic Society, 46 N.Y.U.L.REv. 653, 658-60 (1971). 
responsible and those who are not, and between those who should be punished and those who should be treated. It is this aspect of the defense that has resulted in some serious inequities. Although successful insanity pleas may be rare, defendants found not guilty by reason of insanity face mandatory commitment to mental hospitals for indefinite terms.

Until recently most critics of the M'Naghten Rule have wanted not only to retain the traditional notion that a man should not be convicted of a crime unless he is mentally responsible, but to enlarge the area within which he can plead that by reason of some mental defect, he could not have helped doing what he did. Now some critics want to eliminate the notion of mens rea altogether, that is they wish to throw out any idea of "a guilty mind" or at least to allow it to wither away. In effect, this means that we should altogether abandon the notion of punishing a person for what he or she knowingly and willingly did wrong and substitute a system of "social hygiene," under which conviction would be automatic once the actual crime has been proved. The courts would then set about deciding what should be done with the criminal in light of what was best for him and for society as a whole.

In the United Kingdom a big stride has already been taken in the direction of establishing the therapeutic state, with the passage of the Mental Health Act of $1958 .^{37}$ This provides that while a person who is sane under the M'Naghten Rule must still be convicted, the courts may order his detention for medical treatment in a mental hospital in place of passing a penal sentence. These powers have come to be widely used. The Act "provides that an alleged mentally disordered person may be hospitalized indefinitely on the recommendation of two private physicians, without prior requirement of a court or other hearing." 38

Our only concern, say these reformers, when we have an offender to deal with, is with the future and with the prevention of further crime, the protection of society and, if possible, the cure of the offender. This revolutionary doctrine has been most powerfully advocated by Lady Barbara Wootton in Crime and The Criminal Law. ${ }^{39}$ Lady Wootton argues that if the aim of the law is the prevention of socially damaging actions, the traditional doctrine which looks to the offender's culpability puts his guilty mind (mens rea) "in the wrong place." His state of mind should be considered not before but after conviction, and his acquittal must remain clear-cut.

Another argument Lady Wootton puts forward is that the traditional doctrine of criminal responsibility smacks too much of the retributive theory of punishment, a theory which Lady Wootton, a determinist, finds barbarous and irrational. A third reason she gives for redirecting the aims of the criminal law is that since we can never know what goes on in someone else's mind in any case, we have no possible way of discovering whether the element of "mental guilt" was present. In

37. Mental Health Act, 7 and 8 Eliz. 2, c. 72 (1958).

38. KitTrie, supra note 18 , at 81 .

39. Lady Wootton, Crime and the Criminal Law: Reflections of a Magistrate and Social SCientist (1963). 

mere product of instinct, heredity, and environment, we feed the nihilism to which modern man is, in any case, prone. I became acquainted with the last stage of that corruption in my second concentration camp, Auschwitz. The gas chambers of Auschwitz were the ultimate consequence of the theory that man is nothing but the product of heredity and environment-or, as the Nazis liked to say, of "Blood and Soil." I am absolutely convinced that the gas chambers of Auschwitz, Treblinka and Maidanek were ultimately prepared not in some Ministry or other in Berlin, but rather at the desks and in the lecture halls of nihilistic scientists and philosophers [to which I might add positivistic lawyers and judges.] ${ }^{42}$

If we allowed individual responsibility and retributive punishment to disappear from the criminal law, what would be lost in the process? Is the therapeutic state as benevolent and kind as its advocates and builders claim it to be? I shall now proceed to answer these questions in light of the growing criticism of the therapeutic ideology of crime control.

\section{The Loss of Individual Freedom}

In addition to the depersonalization of the offender, the second casualty of the therapeutic ideology will be, and has already been in the United States as in the Soviet Union, individual freedom. The principle of just retribution prevents excessive severity, on the one hand, and extreme leniency on the other, in the administration of criminal justice. If deterrence or therapy becomes the sole guiding principle in this matter, then great injustice will be the consequence, since any deterrence or any "treatment" for any crime could be imposed provided it was calculated to deter others or provided it would cure the miscreant of his mischief. As Professor H. L. A. Hart warned us in The Morality of the Criminal Law:

My reasons for not joining them [Wootton and others, in their demand for the elimination of the whole doctrine of mens rea] consist of misgivings on three principal points. The first concerns individual freedom. In a system in which proof of mens rea is no longer a necessary condition for conviction, the occasions for official interferences with our lives and for compulsion will be vastly increased. Take, for example, the notion of a criminal assault. If the doctrine of mens rea were swept away, every blow, even if it was apparent to a policeman that it was purely accidental or merely careless and therefore not, according to the present law, a criminal assault, would be a matter for investigation under the new scheme, since the possibilities of a curable or treatable condition would have to be investigated and the condition if serious treated by medical or penal methods. ${ }^{43}$

In criminal justice and law there is a fundamental principle that a generally accepted standard of conduct should be applicable to all citizens alike. Medical principles run directly counter to this: each person's needs must be assessed and his disabilities treated, according to his individual constitution and circumstances. It may be inferred that, if neither retribution nor deterrence were allowed to influence the sentence passed upon an offender who was deemed irresponsible or only partially responsible because of some mental infirmity, there would be no such problem as occasioned the M'Naghten Rule. The offender would be on the same footing as a mentally disturbed person who has committed no crime (but who may

42. V. Franke, The Doctor and the Soul xviii (1971).

43. H. Hart, The Morality of the Criminal Law: Two Lectures 26 (1964). 
be dangerous to society ai large). His treatment, in the view of the reformers, would be that most suited to the betterment of his mental ills.

For the criminal who is held to be fully responsible, such a state of affairs is remote because the methods of treatment available at present cannot be depended on or expected to bring about the desired changes in motive and conduct. Even in some forms of mental abnormality, especially psychopathic personality, which may justify the defense of diminished responsibility, it is doubtful whether psychiatric treatment can predictably effect improvement.

Once we discard the doctrines of just retribution and individual responsibility for wrongdoing and replace these with the doctrines of legal determinism and therapy, there will be nothing left to prevent the Justice Department or the states' attorney generals from seeking to imprison any citizen they dislike for his or her political or religious opinions, on the grounds that some atheist "expert" thinks he or she is socially maladjusted or even sick. ${ }^{44}$ If crime and disease are to be regarded as the same thing, it follows that any state of mind the government chooses to call "disease" can be treated as anti-social behavior and compulsorily cured. It will be futile to plead that states of mind which displease the government or which seem aberrant to psychiatric experts need not always involve moral turpitude and do not therefore deserve forfeiture of freedom. Our new legal masters and therapists will no longer be using the concepts of just desert and punishment but those of disease and cure.

Definitional boundaries for criminal behavior disappear in the therapeutic state. As Lady Wootton noted:

Medical crimes are those that doctors treat and crimes that doctors treat are medical crimes. It would seem that psychiatrists are not afraid of such tautologies: they are, for example, of a piece with the astonishing definition of mental illness recommended for statutory use by the Committee on Psychiatry and Law of the U.S. Group for the Advancement on Psychiatry. According to this, 'Mental illness' shall mean an illness which so lessens the capacity of a person to use (maintain) his judgment, discretion and control in the conduct of his affairs and social relations as to warrant his commitment to a mental institution. By this formula, it should be noted that committal to an institution is justified by the presence of mental illness, yet this mental illness is itself defined only in terms of the need for committal. ${ }^{45}$

Under this definition wrongful detention in a mental hospital becomes impossible, inasmuch as no room is left for any criterion of health and sickness other than the fact of commitment. The same committee would go even further and would have Congress revise the criminal code in such a way that no person could be "convicted of any criminal charge when at the time he committed the act with

44. The vagaries, unpredictability, and "arbitrary and idiosyncratic standards" actually employed by psychiatrists were exposed in Pugh, The Insanity Defense in Operation: A Practicing Psychiatrist Vieus Durham and Brawner, 1973 WASH. U.L.Q. 87, 96: "Other extraneous factors also determined some doctors' decisions. Some doctors seemed to have the 'policy' that anyone who committed a sex crime was insane. Some doctors tended to find a defendant insane if they felt the hospital could 'help' him-or if they felt sorry for him. One psychologist had a racial quirk: though he might find black defendants either sane or insane, he invariably found any white defendant to be insane."

45. Quoted by Lady Wootton in Social Science and Social Pathology 244 (1959). Her whole chapter on "Mental Disorder and Criminal Responsibility" deserves the closest study. 
which he is charged he was suffering with mental illness," as just defined by the Committee in the quotation above, "and in consequence thereof, he committed the act." 46 Those who determine fitness for commitment by a criterion which makes their own judgment infallible would accordingly decide with supposed equal "scientific infallibility" the question of moral responsibility. No totalitarian dictator could ask for greater powers over his fellow citizens.

Kittrie argues convincingly in this connection that the standards determining the need for treatment are not only vague in the extreme, but also lack an adequate basis in tested theory; and they are shot through with the value judgments of their proponents. Second, these standards are used in an arbitrary manner without the safeguards of due process of law. ${ }^{47}$

\section{The Overthrow of the Rule of Law by the Therapeutic State}

The dangers inherent in the therapeutic state also include the loss of the rule of law, if not its complete overthrow. For example, Kittrie notes the case of the California physician who justified an individual's involuntary commitment to a mental asylum on the grounds that the individual had "paranoid delusions and feelings of persecution"48 and might seek redress for his persecution. The physician "'had no assurance that such redress would be of an orderly or lawful type." 49 In Georgia, a young woman was similarly confined on the basis of evidence that she had joined the Jehovah's Witnesses, spent many hours away from home knocking at strange doors, and "had taken to sitting by the roadside at night."

Kittrie also refers to the gross miscarriage of justice in the case of Frederick Lynch, charged in the District of Columbia Municipal Court with passing bad checks. ${ }^{51}$ In spite of his statement that he was mentally responsible at the time the crime was committed, Lynch was found guilty by reason of insanity and was confined to a mental hospital, where he later committed suicide. "By its very nature," the United States Court of Appeals for the District of Columbia said on appeal, "a jail sentence is for a specified period of time, while by its very nature hospitalization, to be effective, must be initially for an indeterminate period." 52 The Court continued as follows:

The length of his hospitalization must depend solely on his need (or lack of it) for further treatment. It is true that he may be hospitalized for a longer time than the maximum jail sentence provided by statute. . . Hospitalization .. . bears no relation to a jail sentence. A jail sentence is punitive and is to be imposed by the judge within the limits set by the legislature. Hospitalization is remedial and its limits are determined by the condition to be treated. ${ }^{53}$

46. Id.

47. KitTrie, supra note 18, at 362-371, "An Audit for the Therapeutic State" and "The Absence of Procedural Safeguards."

48. Id., at 363 .

49. Id., citing Brock v. Southern Pacific Co., 195 P.2d 66, 76 (Cal. 1948).

50. KitTrie, supra note 18, at 363. The case is Paul v. Longino, 28 S.E.2d 286, 289 (Ga. 1943).

51. KitTrie, supra note 18 , at $43-44$. The case is Overholser v. Lynch, 109 U.S. App.D.C. 404 (1959).

52. Overholser v. Lynch, 288 F.2d 388, 393 (D.C.Cir. 1961), rev'd, 369 U.S. 705 (1962).

53. Id., at 394 . 
The U.S. Supreme Court finally reversed this disgraceful decision but only on the narrow technical ground that a person found not guilty by reason of insanity, but who refused to plead this defense, may not automatically be committed to a mental hospital. Rather, a civil procedure is required. ${ }^{54}$

While deploring the decision of the U.S. Court of Appeals, Kittrie nevertheless is still imbued with the principles of the reform school in modern penology. This is reflected among the ten items forming Kittrie's Bill of Rights: (1) "No person shall be compelled to undergo treatment except for the defense of society;" (3) "No social sanctions may be invoked unless the person subjected to treatment has demonstrated a clear and present danger through truly harmful behavior which is immediately forthcoming;" (4) "No person shall be subjected to involuntary incarceration or treatment on the basis of a finding of a general condition or status alone. Nor shall the mere conviction of a crime or a finding of not guilty by reason of insanity suffice to have a person automatically committed or treated;" and (7) "An involuntary patient shall have the right to receive treatment." 55

This Bill of Rights reflects most of the main planks in the reform platform. It allows for prediction of future dangerousness; it allows for involuntary treatment; it accepts the insanity defense; and it argues for a right to treatment for those committed against their will. Further, Kittrie accepts the medicalization of everyday problems, calling racism, for example, the number one public health problem in the United States. Hence he calls for a restructuring of society rather than of individuals, viewing individual responsibility as an outmoded concept.

According to Stone, another member of the reform school, it is now obvious that (1) the mega-institutions presided over by the mental health professions are an acknowledged disaster; (2) community health centers have not proved to be the panacea promised by their zealous advocates; and (3) people have become increasingly distrustful of the coercive use of psychiatry in dealing with the "misfits" of society. He points out that "[f]ive years into the decade of the seventies there is enough evidence to suggest that the United States is engaged in all-out war over the fate of the mentally ill." 56

While psychiatry may well have its proper function to perform in criminology and penology and while we may welcome at least some of its insights into human nature, e.g., its exposure of the "unconscious" realm of the psyche, it is exceeding its proper area of competence when it seeks to abolish justice altogether in favor of medicine. The criminal law must have its own proper definition of legal liability, accountability and individual responsibility if it is to remain law. Such liability and responsibility cannot be defined by psychiatrists or physicians but must be determined by judges and juries. The legal definition of crime and punishment may take account of the psychical, social and biological aspects of human behavior. Then, in the light of such knowledge and information about the defendant, the

54. D.C. Code Ann $\$ 24-301$ (d) (1967), quoted in Kitrrie, supra note 18, at 44. See also Arens, Due Process and the Rights of the Mentally Ill: The Strange Case of Frederick Lynch, 13 CATH. U.L. Rev. 3 (1964).

55. Id., at 402-04.

56. A. Stone, Mental Health and Law: A System in Transition $1-2$ (1975). 
judge or jury can try to weigh the conflict between the interests of the accused and those of society in the scales of justice.

\section{The Growing Inhumanity of America's Humanist Law Reformers}

Once Americans have surrendered all objective standards of morality, legality and justice as revealed in the Word of God, as well as all principles of individual accountability for wrongdoing, then we shall find that we have placed ourselves entirely at the mercy of the so-called conditioners. Such conditioners would apply the methods of B. F. Skinner's operant conditioning, including his so-called positive and negative reinforcements. ${ }^{57}$ Merciful though the methods of these penal therapists and psychiatrists might appear at first sight, the adoption of such methods now means that every citizen, from the moment he breaks any law or infringes any governmental regulation, will find himself deprived of the rights of a human being. By removing the concept of retribution and just desert in punishment, our secular humanist and atheist social scientists, penologists, law enforcement and prison officials, and social workers have in fact reduced the offender from the status of a moral subject made in God's image to that of an object for scientific manipulation and behavior modification. In Behavior Mod and The Managed Society, Geiser describes many of the methods now being used under the general heading of behavior modification. ${ }^{58}$

Behavior therapists use various types of behavior modification, namely therapeutic techniques that apply the learning principles of operant and classical conditioning to bring about positive changes in human conduct. Thus classical conditioning, the pairing of a conditioned stimulus and an unconditioned stimulus, can be used to condition an aversion when the latter causes pain or discomfort. In aversion therapy, the sights, sounds, odors, and motions of a bad habit such as drinking or smoking are associated with pain or other aversive events. Thus, the undesirable response becomes associated with an aversion which inhibits its occurrence. ${ }^{59}$

Behavior modification also makes use of operant principles. The most commonly used principles are: positive reinforcement, nonreinforcement, extinction, punishment, shaping, stimulus control, and time out. Through the application of these principles, behavior modification is used to stamp out undesirable responses and to promote constructive behavior. ${ }^{60}$ Glover has described other methods used

57. B. Skinner, Beyond Freedom and Dignity (1971). For a critique, consult F. Schaeffer, How Should We Then Live? 228-45 (1976) (ch. 12, Manipulation and the New Elite) and F. SCHAEFFER, BACK to Freedom and Dignity (1973).

58. R. Geiser, Behavior Mod and the Managed Society $48-49$ (1976). Cf. E. Fersch, Psychology and Psychiatry in Courts and Corrections (1980).

59. Aversion therapy problems are discussed in Note, Aversion Therapy: Its Limited Potential for Use in the Correctional Setting, 26 Stan. L. Rev. 1327 (1974); in Moya \& Achtenberg, Behavior Modification: Legal Limitations in Methods and Goals, 50 Notre Dame Lawyer 230 (1974); and in Note, Aversion Therapy, Punishment as Treatment and Treatment as Cruel and Unusual Punishment, 49 S. CAL. L. REv. 880 (1976).

60. An excellent treatment of the use of such behavior modification programs in hospitals and prisons is in Singer, Consent of the Unfree: Medical Experimentation and Behavior Modification in the Closed Institution, 1 L. \& HumaN BeHav. 1 \& 101 (1977). The reader should also consult Symposium, Behavior Modification in Prisons, 13 Aм. Crim. L. REv. 1 (1975). 
in the treatment of criminals as ranging from hypnosis, psychoanalysis, to the use of psychotropic drugs, and electric shock therapy. ${ }^{61}$ For obvious reasons such methods of "treatment" are kept generally well hidden from the American public; and many of the persons who have undergone such "treatment" remain hidden from the public gaze in prison cells or graves, as in the case of John Gates. ${ }^{62}$

Commitment procedures may be likewise perfunctory, despite recent legal changes. David Mechanic, studying two large mental hospitals in California, reported that all persons who appeared at the hospitals were admitted, regardless of their ability to function outside the hospital. Not once did a psychiatrist advise a person that he did not need treatment. ${ }^{63}$ In Mental Health and Social Policy, Mechanic points out that "commitment process has the form of due process of law but is actually vacuous since the decision tends to be predetermined." ${ }^{\text {" }}$ Dorothy Miller and Michael Schwartz, observing 58 individual hearings before a county lunacy commission, found that the hearings were routine rituals averaging only four minutes each. ${ }^{65}$ Finally Kutner, describing superficial hearing procedures at the Cook County Mental Health Clinic in Chicago, reports that the physicians recommended commitment in 77 percent of the cases, presuming the allegedly mentally ill persons to be insane and placing the burden of proof upon them rather than upon their accusers. $^{66}$

\section{The Supreme Court's Subservience to the Therapeutic State}

The failure of legal procedures to provide the intended legal safeguards for persons accused of being mentally ill is illustrated by two recent Supreme Court cases.

61. Glover, supra note 2, at 79-114 (Part IV, The Criminal Psychopath). The literature on psychosurgery also continues to expand. One of the most valuable discussions is the Report and Recommendations Concerning Psychosurgery, National Commission for the Protection of Human Subjects of Biomedical and Behavioral Research (Dec. 1976).

62. A terrifying example of such "treatment" was that administered to John Gates, a small businessman in Clinton, Tennessee, who in 1957 attempted to resist by legal action the attempt of the government to integrate his children. Gates, a healthy and vigorous man, was hauled off against his will to a nearby mental health clinic. Eight days later his emaciated dead body was delivered to his widow. According to R. P. Oliver: "There were blackened areas on the corpse's forehead, and the inside of the mouth was burned and charred to the depth of about one-eight of an inch of flesh resembling the burns produced when human flesh is contacted by high voltage electricity. . . Gates was admittedly subjected to electric shock therapy ... . and he died when some overly enthusiastic social reformer turned on too much current." Dr. Oliver then points out: "There are of course other forms of "loving care' for mental and criminal patients. A lobotomy can reduce an intelligent man to a huddled lump of living but scarcely conscious protoplasm." Most decent-minded American citizens surely would agree that, given such "loving care," they would prefer to be punished in the old fashioned way. Even though guilty of crime, criminals are not rats and guinea pigs to be experimented upon by doctors, psychiatrists and nurses. R. Oliver, Brainwashing in the U.S.A. 15-20 (1961).

63. Mechanic, Some Factors in Identifying and Defining Mental Illness, 46 MENTAL HyGIENE 66, 70 (1972).

64. D. Mechanic, Mental Health and Social Policy 127 (1969)

65. Miller and Schwartz, County Lunacy Commission Hearings: Some Observations of Commitments to a State Mental Hospital, 14 Soc. Prob. 26 (1966). This study, with others, is mentioned by the U.S. Supreme Court in its recent decision in Parham v. J. R., 442 U.S. 584, 609-10 n.17 (1979).

66. Kutner, The Illusion of Due Process in Commitment Proceedings, 57 N.W.U. L. Rev. 383, 385 (1962). 
1. The Parham Case. In Parham v. J. $R .^{67}$ minor children brought an action alleging that they and other class members had been deprived of their liberty without procedural due process by virtue of Georgia's mental health laws which permit voluntary admission of minor children to mental hospitals by parents or guardians. The trial court ruled the laws unconstitutional. ${ }^{68}$ On appeal, Chief Justice Burger, while ruling that Georgia's procedures for admitting a child for treatment to a state mental hospital are reasonable and consistent with constitutional guarantees, held that the risk of error inherent in a parental decision to have their child institutionalized for mental health care is sufficiently great to require that some kind of inquiry should be made by a medical "neutral factfinder" to determine whether statutory requirements for admission have been satisfied.

Two state interests, however, work to limit the amount of due process required in the hearings. One, the state's parens patriae mission to care for the mental health of children, "cannot be fulfilled if the parents are unwilling to take advantage of the opportunities because the admission process is too onerous, too embarrassing or too contentious." ${ }^{69}$ The second interest is "the utilization of the time of psychiatrists, psychologists and other behavioral specialists in preparing for and participating in hearings rather than performing the task for which their special training has fitted them."70 Balanced against the rights and prerogatives of parents and children in the voluntary commitment setting, these interests are reflected in a modified Due Process hearing.

Although a formal or quasi-formal hearing is not required and inquiry need not be conducted by a law-trained or judicial or administrative officer, appointed by a court of law, such inquiry must carefully probe into the child's background using all available sources. The Chief Justice further ruled that it is necessary that the decision-maker, in this case the psychiatrist, should have the authority to refuse to admit any child to a mental hospital who does not satisfy medical standards for admission. The child's continuing need for commitment must be reviewed periodically by similarly independent medical examination procedure.

The Chief Justice seems to have forgotten that he was appointed to administer justice and to protect the liberties of American citizens, especially American juveniles too young to protect themselves and not to save the taxpayers their money or psychiatrists their time. Is the time spent by psychiatrists in courtrooms now to be considered of more importance than the need to protect the innocent from deprivation of their freedoms?

The Chief Justice makes much of protecting the due process of law which exists to protect each American citizen but then he hands over the ultimate decision of whether a minor shall be committed to a mental hospital to psychiatrists who are not qualified by their training to decide such legal matters. For Burger it would seem medical science takes priority at this point over jurisprudence. He adroitly writes:

67. Parham v. J. R., 442 U.S. 584, 99 S. Ct. 2493 (1979).

68. J. L. v. Parham, 412 F. Supp. 112 (M.D. Ga. 1976).

69. $99 \mathrm{~S}$. Ct. at 2505.

70. Id., at 2506 . 
[The required neutrality] inquiry must carefully probe the child's background using all available resources, including, but not limited to parents, schools and other social agencies. Of course, the review must also include an interview with the child. It is necessary that the decision-maker have the authority to refuse to admit any child who does not satisfy the medical standards for admission. Finally, it is necessary that the child's continuing need for commitment be reviewed periodically by a similarly independent procedure. ${ }^{71}$ (Emphasis added.)

Here let it be observed that commitment no longer depends upon legal considerations but upon medical ones. For this reason I agree with Justice Brennan's opinion in the case, in which he pointed out that

... the chances of an erroneous commitment decision are particularly great where children are involved. Even under the best of circumstances psychiatric diagnosis and therapy decisions are fraught with uncertainties [cite omitted]. These uncertainties are aggravated when, as under the Georgia practice, the psychiatrist interviews the child during a period of abnormal stress in connection with commitment, and without adequate time or opportunity to become acquainted with the patient [cite omitted $]^{72}$

Justice Brennan then pointed out:

These compounded uncertainties often lead to erroneous commitments since psychiatrists tend to err on the side of medical caution and therefore hospitalize patients for whom other dispositions would be more beneficial. . . The National Institute of Mental Health recently found that only 36 percent of patients below age 20 who were confined at St. Elizabeth's Hospital actually required such hospitalization. . . . Of particular relevance to this case, a Georgia study Commission on Mental Health Services for Children and Youth concluded that more than half of the State's institutionalized children were not in need of confinement if other forms of care were made available or used [cites omitted]. ${ }^{73}$

To justify his subservience, if not surrender to the dictates of the Therapeutic State, the Chief Justice removes institutionalization from the legal realm and places it squarely in the hands of doctors and parents. Burger has fallen into the snare which exists in the borderland between psychiatry and the courts. Since objective criteria for diagnosing most mental illness are unavailable, it follows that the criteria to establish whether a juvenile was mentally ill at the time he was committed is also wanting. Paradoxically, the Chief Justice is thus obliged by his own faith in scientism to call upon a psychiatrist for an expert opinion, even though he is fully aware that most psychiatrists acknowledge in their saner moments that their expertise is limited and patchy. Burger thus stated in his opinion that "due process has never been thought to require that the neutral and detached trier of fact be law-trained . . . thus, a staff physician will suffice, so long as he or she is free to evaluate independently the child's mental and emotional condition and need for treatment." 74 Although the court must ultimately make decisions about the defendant's fitness to plead, in this case it transferred many of the tricky questions to a professional group, which is not sure to provide an objective, accurate evaluation.

71. Id.

72. Id., at 2517 (Brennan, J.)

73. Id., at 2517-18 (Brennan, J.).

74. Id., at 2506-07. 
Burger even further whittled down the due process of law in the case before him by arguing that a formal judicial hearing before the commitment of a person to a mental hospital if he were a minor would intrude upon his relationship with his parents. It "[a fact-finding hearing] poses a significant intrusion into the parentchild relationship. Pitting the parents and child as adversaries often will be at odds with the presumption that parents act in the best interests of the child." 75

The weakness of this argument in favor of foregoing the observance of due process of law is that in the case in question the parents had proved themselves unworthy of that august responsibility. The parents had in fact given up their rights over their child to the state of Georgia long before J. R. brought his case to court! His battle for freedom was against the social workers who had had him committed, not against his parents. As to the right of social workers to commit someone else's child, Brennan had this to say:

To my mind, there is no justification for denying children committed by their social workers the prior hearings that the Constitution typically requires. In the first place, such children cannot be said to have waived their rights to a prior hearing simply because their social workers wished them to be confined. The rule that parents speak for their children, even if it were applicable in the commitment context, cannot be transmuted into a rule that state social workers speak for their minor clients. The rule in favor of deference to parental authority is designed to shield parental control of child-rearing from the state [cite omitted]. ${ }^{76}$

2. O'Connor $v$. Donaldson. ${ }^{77}$ In this case a mental patient named Kenneth Donaldson who had been confined for almost 15 years against his own choice "for care, maintenance and treatment" in the Florida State Hospital at Chattahoochee, brought an action for damages under 42 U.S.C. $\$ 1983$ against Dr. J. B. O'Connor, the hospital's superintendent, and other staff members, alleging that they had intentionally and maliciously deprived him of his constitutional right to liberty. Throughout his confinement Donaldson repeatedly, but unsuccessfully, demanded his release claiming that he was dangerous to no one, that he was not mentally ill, and that, at any rate, the hospital was not providing treatment for his supposed illness. In February of 1971, Donaldson brought a lawsuit in district court claiming damages against O'Connor. After a four day trial, the jury returned a verdict assessing both compensatory and punitive damages against O'Connor and a codefendant. The Court of Appeals for the Fifth Circuit affirmed the judgment. ${ }^{78}$

In delivering the Supreme Court's decision, Justice Stewart held: "A State cannot constitutionally confine without more [justification] a nondangerous individual who is capable of surviving safely in freedom by himself or with the help of willing and responsible family members or friends. Since the jury found, upon ample evidence, that O'Connor, as an agent of the State, knowingly did so confine Donaldson, it properly concluded that O'Connor had violated Donaldson's constitu-

75. Id., at 2508 .

76. Id., at $2521-22$ (Brennan, J.).

77. 422 U.S. 563 (1975).

78. 493 F.2d 507. 
tional right of freedom."79 Justice Stewart, supporting his decision, observed that the mere existence of a state law authorizing confinement is not a constitutionally valid basis for confinement per se. ${ }^{80}$ And even if the initial confinement is permissible, the state must justify continued confinement. ${ }^{81}$

But Justice Stewart carefully narrowed the scope of his decision by refusing "to decide whether mentally ill persons dangerous to themselves or to others have a right to treatment upon compulsory confinement by the State, or whether the State may compulsorily confine a nondangerous, mentally ill individual for the purpose of treatment." ${ }^{, 82}$ In this case, then, the Court established that the plaintiff had not received treatment during his commitment, but did not consider the broader concept of the "right to treatment." It would seem that the Supreme Court out of deference to the medical establishment deliberately avoided dealing with the basic issue involved in the involuntary treatment of the mentally ill. Justice Stewart said as much in the following passage:

We need not decide whether, when, or by what procedures, a mentally ill person may be confined by the State on any of the grounds which, under contemporary statutes, are generally advanced to justify involuntary confinement of such a person-to prevent injury to the public, to ensure his own survival or safety, or to alleviate or cure his illness. ${ }^{83}$

3. A Liberty Interest? What is surely needed are some clear legal guidelines from the Supreme Court regarding: (1) Stricter due process procedures of civil commitment and (2) Balancing the state's interest in providing care and treatment and the protection of other members of society with the patient's fundamental right to individual liberty. The right to liberty surely requires greater justification than merely using the label "mentally ill" as an excuse to deprive an individual of his freedom.

Over the past decade, certain experts in mental-health law have been trying to establish the "right to treatment." ${ }^{\text {" }}$ They argue that a patient has a fundamental right to adequate treatment in exchange for being deprived of his freedom. Simple custodial supervision of a patient, such as happened in the case of Kenneth Donaldson, does not constitute treatment in their view. The legal issues involved in the "right to treatment" are bound to come before the Supreme Court before long. On this matter I can only state that I believe that no such "right to treatment" exists any more than there is a "right to food" or a "right to welfare." The issue of voluntariness becomes crucial in the complementary contested "right to refuse treatment," another question not yet resolved by the Supreme Court.

79. 422 U.S. at 576.

80. Id., at 574 .

81. Id., at 575 .

82. $I d$., at 573 .

83. Id., at 573-74.

84. So far the Supreme Court has not recognized such a "right to treatment," but there are some scattered potential precedent-setting cases in the lower courts. See Rennie v. Klein, 462 F. Supp. 1131 (D.N.J. 1978) and Rogers v. Okin (Slip Opinion, lst Cir. Nov. 25, 1980), modifying 478 F. Supp. 1342 (D. Mass. 1979). 
In his article Justice in the Therapeutic State, as well as in his books, Law, Liberty and Psychiatry and Psychiatric Justice, Szasz ${ }^{85}$ has discussed with great acumen and insight the divergent concepts of the Legal State and the Therapeutic State. In his view, with which 1 wholeheartedly concur, the business of the Legal State is "the maintenance of peace through a system of just laws justly administered." ${ }^{86}$ Insofar as it is true to its own nature, the Legal State has no claim on the individual beyond what is set down in the law; for the rest, what the citizen does is none of the State's business. By contrast Szasz observes:

In the scientific-technological conception of the State, therapy is only a means, not an end. The goal of the Therapeutic State is universal health, or at least unfailing relief from suffering. This untroubled state of man and society is a quintessential feature of the medical-therapeutic perspective on politics. Conflict among individuals, and especially between the individual and the State, is invariably seen as a symptom of "illness" or psychopathology, and the primary function of the State is accordingly the removal of such conflict by "therapy"- "therapy" imposed by force, if necessary. It is not difficult to recognize in this imagery of the Therapeutic State, the old Inquisitorial, or the more recent Totalitarian concept of the State, now clothed in the garb of psychiatric treatment. ${ }^{87}$

In short, Szasz believes that liberty can be unwittingly sacrificed by too great a concern for the "cure" of mental illness. According to Szasz, psychiatry is not really a healing science, but a means of social control that permits some people forcibly to incarcerate others whose behavior offends them. The people thus involuntarily committed to mental hospitals are disproportionately the old and the poor, people whose behavior their families and associates do not wish to tolerate. Psychiatrists, for their part, become "jailers" inflicting punishments on the inmates in the form of electric shock treatments, psychosurgery and tranquillizing drug injections. These treatments according to Szasz, are no better than the funeral pyre and the rack of the Spanish Inquisition. ${ }^{88}$

According to Szasz, the distinction between voluntary and involuntary treatment is of the utmost importance. Voluntary treatment, of which he approves, he compares to attending the church of one's choice. He likens involuntary treatment to the process of forced religious conversion. In the case of paresis, for example, in which the disease has a known organic cause, he favors hospital treatment, but on the same voluntary basis as it is afforded to people with other organic diseases.

\section{A Christian Critique of the Therapeutic State}

1. The Nature of the Therapeutic State. By removing the concept of just retribution and just desert in punishment and replacing these with "treatment," the social scientists have in fact reduced the offender from the status of a moral subject to that of an object for scientific manipulation. As C. S. Lewis reminds us, it is only as deserved or undeserved that a sentence can be just or unjust. ${ }^{89}$ After the new

85. See Szasz works, supra notes 10 and 11 , infra note 86 .

86. Szasz, Justice in the Therapeutic State, 11 Comprenensive Psych. 433 (1970).

87. Id. See also Kahle \& Sales, Attitudes of Clinical Psychologists Toward Inwoluntary Civil Commitment Law, 9 Prof. Psych. 428 (1978).

88. SzASz, supra note 10 , at $46-71$

89. LEWIS, supra note 26 , at $2-3$. 
scientific method of "treating" criminals has replaced our present system of punishing them, it will be useless for Christian citizens to object that such scientific "treatment" is unjust since the experts will with perfect logic on their side reply, "Nobody is now talking about just deserts. No one is talking of punishment in your archaic vindictive sense of the word. We no longer think of prisoner $X$ as a person but only as a sociological and psychological function of his heredity acting upon his environment."

The scientistic theory or model of the cause and cure of crime inevitably has this dehumanizing effect upon those subjected to its methods of treatment because such scientistic doctrine is forced by its own logic to reduce the individual person being accused of a crime or of being mentally ill to the level of one of his aspects, in this case, the sociological, psychological and biological aspects. What such "treatment" amounts to, then is that psychiatrists and social workers have been given full legal authority to treat their criminal and civil patients by means of chemotherapy, electric shock treatment, group therapy, sensitivity training, psychosurgery and behavior modification techniques.

In addition, this medical model of the cause and cure of crime would remove sentences from the hands of jurists, lawyers and judges trained in the law, and place them in the hands of technical experts, whose special social sciences expressly refuse to recognize that even the criminal accused of a crime is created in God's image and therefore is to be treated as a person, not as a thing. The express purpose is to destroy all traditional concepts of morality and justice. ${ }^{90}$

These secular humanists and self-styled law-reformers are bent on cutting down the authority of our courts of justice to determine sentence not only in murder cases but in all crimes of a pathological nature. The future of our courts would be limited to determining the accused person's state of mental health. If he is found to be "unhealthy" he would be sentenced for an indefinite term at a mental health center or mental hospital, to be released only upon recommendation. It is admitted that this might involve a longer period of preventive detention than the law now imposes for particular offenses. The patient would be kept confined until some "expert" in mental medicine declared him to be cured of his "maladjustment." Such a deprivation of the criminal's freedom would be justified on the specious grounds that it was not punishment but only "treatment."

C. S. Lewis has warned us that such scientistic "healing" would be just as cruel as any old-fashioned punishment, as the cases of Lynch and Gates I think prove. Lewis writes in The Humanitarian Theory of Punishment:

It may be said that by the continued use of the word punishment and the use of the verb "inflict" I am misrepresenting humanitarians. They are not punishing, not inflicting, only healing. But do not let us be deceived by a name. To be taken without consent from my home and friends; to lose my liberty; to undergo all those

90. For proof of this statement, the reader is referred to the "Humanist Manifesto" of 1932, reprinted in D. Faber (ed.) The Christian Challenge (Nov. 1980), and to C. Lamont, The Philosophy of Humanism (1949), in which open warfare is declared upon the religion of the Bible in the name of the new god of science. See also The Aspen Institute for Humanistic Studies, FreEmen Dig. 3 (1979). 
assaults on my personality which modern psychotherapy knows how to deliver; to be re-made after some pattern of "normality" hatched in a Viennese laboratory ... to know that this process will never end until either my captors have succeeded or I grow wise enough to cheat them with apparent success-who cares whether this is called punishment or not? That it includes most of the elements for which any punishment is feared-shame, exile, bondage, and years eaten by the locust-is obvious. Only enormous ill-desert could justify it; but ill-desert is the very conception which the humanitarian theory has thrown overboard. ${ }^{91}$

2. Historic Refutations of the Therapeutic State. Such a commitment procedure would be a thoroughly retrogressive step, disregarding our cherished civil liberties. It required centuries of struggle to establish the legal principle that government officials and bureaucrats have no right to hold people in custody or in prison indefinitely at their own will and pleasure. It was to prevent such tyranny that the Acts of Habeas Corpus were passed after the Restoration of King Charles II in 1662 and enacted into the American Constitution. ${ }^{92}$ A civil war erupted in England partly over the injustices caused by the notorious Star Chamber, resulting in the establishment of the principle that prison sentences can only be imposed by the courts after due process of trial before a jury of one's peers, according to known and objective rules of law. Now modern secular humanist law reformers would have the American people scrap this historic safeguard of our Christian liberties and return to an "expert" group of officials-the members of the various agencies for release and their secular humanist medical advisers-the same right of arbitrary arrest and indefinite imprisonment which our Puritan ancestors refused to allow to the Stuart kings. ${ }^{93}$

The Anglo-American legal tradition that a court of justice is the proper authority to impose sentences is based on sound reasons. The trial judge and jury are presumably impartial. They have heard all the evidence and have examined the accused's record. The prisoner has an opportunity to be heard on his own behalf and to be defended by attorneys trained in the criminal law. Above all, the proceedings are open so that public and friends will know if there has been a miscarriage of justice. Will these safeguards be present if a prisoner's fate is to be determined by some secret conclave of psychiatrists and prison wardens acting under the authority of statute?

Part of the movement to substitute medicine for legality and morality as the basis of our criminal justice system has been the attempt to reduce the function of the jury in the trial process. Judge Frank criticized the jury system for these reasons: (1) Juries are biased; (2) Lawyers select jurors not to get the facts but to win a case; (3) The jury is able to disregard rules of evidence and the instruction of the judge; (4) In effect its decisions become law, making the jury an unelected legislature; (5) The jury does not ordinarily report the facts upon which its deci-

91. LewIS, supra note 26 , at 6 .

92. P. Devlin, The Criminal Prosecution in England (1959) and Trial by Jury (1956).

93. J. Tanner, English Constitutional Conflicts of The Seventeenth Century, 1603-1689, at 73-75, 98-99, 214 (1928). 5 Sir W. Holdsworth, A History of ENGlish LaW 178-84 (1931). 
sions are based; and (6) Its existence blocks the way to increased use of scientific data, which is the best guarantee of real justice. ${ }^{94}$

Here we have an example of legal scientism at its worst. Frank thinks that scientific methods of discovering truth in physics and chemistry can be applied equally successfully in legal and courtroom procedures. But the court is not a laboratory. Its basic duty is to balance the interests of the accused against the interests of society by seeking to arrive at the truth of the matter in dispute, based upon known rules of legal evidence. In this vital matter it is surely better to depend upon the judgments of "twelve good men and true" than upon a body of experts. If the court is in fact seeking to administer justice and not medicine, the propriety of the penal code, being a moral and a legal question, is a question on which every person has the right to an opinion, not because he or she is an expert lawyer or psychiatrist but simply because he or she is a human being created in God's image. Once the purpose of the court becomes one of meting out deterrents or treatments rather than punishments then, of course, the argument for a trial by jury also collapses. As C. S. Lewis says:

Once we drop the concept of desert the only questions we may now ask about a punishment are whether it deters and whether it cures. But these are not questions on which anyone is entitled to have an opinion simply because he is a man. He is not entitled to an opinion ... . for they are not questions about principle but about matter of fact; and for such . . . to each his own last. Only the expert "penologist" . . in the light of previous experiment, can tell us what is likely to deter; only the psychotherapist can tell us what is likely to cure. ${ }^{95}$

Our Anglo-American experience has shown that the jury system is one of the great bulwarks standing between a tyrannical government and its so-called "expert" advisors and the liberties of the individual citizen. In Trial by Jury, Lord Devlin argues that it is the combination of judge and jury which makes our system of criminal trial not only workable but perhaps better than any so far invented. Since only the wearer of the shoe knows where it pinches it follows that those who are called upon to obey the laws of the land must have some say in their interpretationhence its inclusion in the Constititution in Article III and the Sixth Amendment. ${ }^{96}$

3. Mercilessness of the Therapeutic State. The so-called "humanitarian," scientistic theory of the cause and cure of crime carries as its badge of appeal a semblance of mercy which is wholly false, as the cases I have already invoked above in this paper should prove. That, no doubt, is why this medical model has deceived so many liberal modernist church leaders, ministers and priests in the United States.

According to C. S. Lewis, the error began with Shelley's statement that the distinction between mercy and justice was invented in the courts of tyrants. Lewis then points out that the Christian view has been "that mercy tempered justice or (on the highest level of all) that mercy and justice had met and kissed. The essential act of mercy was to pardon; and the pardon in its very essence involves

94. J. Frank, Courts on Trial 110-20 (1949).

95. Lewis, supra note 26, at 4. Cf. J. Friedman, Retracking America (1973) for a discussion on the role of "experts" in a democratic society.

96. Devlin, supra note 92. 
the recognition of guilt and ill-desert in the recipient. How can you pardon a man for having a gumboil or a club foot? Either he has it or he hasn't got it." 97 Lewis concluded his article with these profound observations which every judge and attorney reading this paper should carefully ponder:

... the humanitarian theory wants simply to abolish justice and substitute mercy for it. This means you start being "kind" to people before you have considered their rights, and then force upon them supposed kindnesses which they in fact had a right to refuse, and finally kindnesses which no one but you will recognize as kindnesses and which the recipient will feel as abominable cruelties. You have overshot the mark. Mercy detached from justice grows unmerciful.

That is the important paradox. As there are plants which flourish only in mountain soil, so it appears that mercy will flower only when it grows in the crannies of the rock of justice. Transplanted to the marshlands of mere humanitarianism, it becomes a man-eating weed, all the more dangerous because it is still called by the same name as the mountain variety. But we ought long ago to have learned our lesson. We should be too old now to be deceived by those humane pretensions which have served to usher in every cruelty of the revolutionary period in which we live. These are the "precious balms" which will "break our heads." 98

The therapeutic model with its false theory of mercy, in effect, also abolishes the State as State. For it no longer recognizes the proper basis of human government as resting in God's delegated power of the sword of justice to officials of human government. ${ }^{99}$ It refuses to recognize that the power of the sword of justice is necessary to restrain the worst consequences of human sinfulness, and that the use of power is necessary for the maintenance of justice.

The choice before us is plain. We can choose to retain the doctrines of just retribution and individual responsibility for wrongdoing as the basis for the criminal justice system in the United States or we can condemn ourselves to be reduced to slaves of the Therapeutic State with its scientistic elite. By turning our backs on God's Word and Law revealed in creation and in the Holy Scriptures, we shall discover that all defense against the exercise of arbitrary power has vanished at the same time. If we refuse to accept the God of the Bible as the source of all our legal norms and principles of justice and law, we shall finish up having tyrants as our masters; since experience has proved that only the God and Father of the Lord Jesus Christ can subject the power of rulers, of judges, of police as well as the ordinary citizen to conscience. ${ }^{100}$

\section{The Christian Legal Response to the Therapeutic State}

What response should Christians make to the therapeutic power-state, the "disease" model of criminality upon which it is based and its treatment approach to offenders?

97. LEwIS, supra note 26 , at 11 .

98. Id., at 11-12.

99. Romans 13. Cf. H. Dooyeweerd, The Christian Idea of the State (1968).

100. W. Ebenstein, C. Pritchett, H. Turner, \& D. Mann, American Democracy in World Perspective 25-27 (1967); A. de Tocqueville, Democracy in America (1835); A. Woodhouse (ed.), Puritanism and Liberty (1938); C. Hill., The Century of Revolution, 1603-1714 129-30, 177.78, 225-27, 289-90 (1961). 
In the first place, Christians should return to the biblical teachings regarding the nature of man as a sinner, of the state as God's restraint upon crime and the need for punishment for those proved guilty of crime beyond a reasonable doubt. These biblical premises for criminology may be compared with what Ellsworth $\mathrm{A}$. Fersch has termed "the rethinking model," which he says is reflected in the works of James Q. Wilson, Thomas Szasz, Justice Fleming and Ernest Van den Haag. According to Fersch "the first assumption of the rethinking method is that man's behavior is the product of his free will, that he is generally free to act in conformity with laws or to defy them ... . The second assumption is that some men are evil, or bad, or wicked, or not to be trusted, or destructive, or whatever; and that those men need to be sequestered or removed from the company of those on whom they would prey." 101

While the Christian would agree with this assessment of criminals, he would add the further assumption of both corporate as well as individual responsibility for wrongdoing. In the biblical teaching both the individual criminal and the society of which he is a member share responsibility for his crime.

The biblical-Christian way of stating society's responsibility is in terms of the doctrine of both original and actual sinfulness. As Herbert Farmer explains:

Sin being a perversion of personal relations, the consequences of it are bound to permeate into the lives of all. . . . No man can be judged wholly responsible for the darkness, perversity and discord of his own being, for he could be wholly responsible for it only by being an isolated person, that is by ceasing to be a person at all. On the other hand, no man can be judged wholly without responsibility for it, for in that case he would not be a person. In some deep way we are all corrupted by the general sinful state of humanity into which we are born, and yet we make the corruption our own, and make it still more deeply part of us, by our own choice and decision, by putting our own causality as persons into it. ${ }^{102}$

To a very large extent, we all carry some share of blame for the wrongful acts of others. Obviously each person is individually accountable for his or her own conduct, but there is a very real sense in which we all share responsibility for the sins and crimes that other persons commit. Such a society has no moral right to become indignant over the crimes of one criminal; instead it should be as horrified at his crime as if it were its own. ${ }^{103}$ Christians, of all people, every time they hear that a crime has been committed will feel with William Bradshaw, the great Puritan, as he witnessed a criminal going to Tyburn Hill to be hanged: "There but for the grace of God go I!" Whoever thinks in this way will have lost all desire to demand retribution in the traditional sense of revenge. ${ }^{104}$

If the advocates of the punitive ideology tend to ignore society's share of responsibility for crime, the advocates of the therapeutic school have forgotten the individual's psychological and spiritual need to make expiation for his own wrong-

101. Fersch, supra note 58, at 41-42.

102. FARMER, supra note 13 , at 92-95 (1954).

103. See D. Taft \& R. England, Criminology 275-79 (1964) for a discussion of the criminogenic nature of American culture.

104. Brunner, supra note 13 , at 194-98. 
doing. We admit that in the desire of many people for expiation and retribution for wrongdoing there often lurks a great deal of primitive desire for revenge, a great amount of Pharisaism, as well as frequently hidden sadistic tendencies. But even after due allowance has been made for these unchristian factors, there still remains a remnant of truth in the desire for retribution which can only be ignored by legal and penological thought at its peril. ${ }^{105}$ The most convincing proof of this traditional element in punishment is the criminal's own sense of the need for expiation. Any person who is not utterly devoid of all moral sense desires in some way to "expatriate" the wrong he has done, once he recognizes that it is wrong. Even if only in some vicarious way, he wants to make "amends" for his crime. No nineteenth century Christian thinker understood this need of the criminal to expiate his crime better than the Russian writer Dostoevsky.

Dostoevsky insisted that every crime needed to be met by a punishment that has its sanction in man's free conscience rather than in exterior law. He affirmed this in the name of the dignity and freedom of man, who cannot agree to brand himself as the passive creature of his circumstances. If there be such a thing as man, if there be human personality, then evil has an inward origin, and it befits the dignity of man and his divine origin that he should recognize that suffering redeems wrongdoing. Evil is expiated in the inevitable consequences that it carries with it and not only by external chastisement. The torments of a person's conscience are more frightening than the severities of the penal code, and the criminal looks upon his legal punishment as a relief from his moral torture. The human soul itself seeks the sword of justice that the State wields, and invites its punitive stroke; punishment is a step on the road to moral restoration. ${ }^{106}$

The next step in the Christian response to the Therapeutic State thus consists in recognizing the need for punishment rather than "treatment" by the State of convicted criminals. Fersch appears to agree: "The rethinking method assumes a legal model, recognizing that both psychology and psychiatry and the law have engaged in reciprocal escalation of hopes, claims, and demands, and arguing that that escalation should stop, and that in fact using psychology and psychiatry in courts and corrections should be de-emphasized." 107 In his view the function of the courts is to administer justice, not medicine, to those convicted of crimes. He points out that "While the reform focus has been on mental health, the rethinking focus has been on the law." 108 Fersch contrasts the two approaches as follows:

Under the reform method, expert testimony is permitted, even encouraged, in courts concerning such matters as the insanity defense, the prediction of individuals' future dangerousness, and the determination of competency to stand trial. Under the rethinking method, on the other hand, the practices in courts are considerably different. No expert testimony is permitted in courts.

Further, in terms of the relationship between acts and consequences, there is a

105. F. Lord Longford, The Idea of Punishment (1948).

106. For a penetrating discussion of Dostoevsky's view of crime and punishment the reader should consult N. Berdyaev, Dostoevsky (1959) and V. Ivanov, Freedom and the Tragic Life (1952).

107. FersCh, supra note 58 , at 42 .

108. Id, at 46 . 
great difference between practices under the reform method and practices under the rethinking method. In the legal practice, for example, the consequence follows the act. A person assaulting another is the act. The legal proceeding then brings about the consequence; the person is found innocent or guilty; if guilty there is some sort of punishment or rehabilitative effort. Act, therefore, has preceded consequence. ${ }^{109}$

According to Fersch the "rethinking method" of dealing with criminals will involve the following consequences: (1) the contraction of court involvement in the lives of individuals and of forensic psychologists and psychiatrists involvement in the operations of the court; ${ }^{110}(2)$ it only permits "therapy which is voluntary . . . there is no mandatory or coerced therapy"; ${ }^{11}$ (3) it "has but one system for those found guilty of illegal acts, and that is the criminal justice system." 112

Fersch's program thus concurs with the Christian view that henceforth all therapy must be placed upon a voluntary basis. The convicted criminal may choose to undergo punishment in a prison rather than "treatment" in a mental hospital. Surely that is the criminal's constitutional right as guaranteed by the Fifth and Fourteenth Amendments.

I would part company with Fersch's teaching at the point where he teaches that the best way to deal with such problems as homosexuality, rape and drug use is to de-criminalize them. Marijuana and heroin use, he writes, "ought to be neither crimes nor diseases. .. . They, like alcohol, are substances that some people enjoy using to their own benefit or to their own detriment. . . The law ought to stay out of the matter except to make sure that correct labeling of the products takes place. ... And there ought to be prohibitions on the purchase or use of the substances for the young." 113

In my view, this approach is similar to the one adopted by the labeling perspective and shares in its defects. These include the following. First, labeling theory tends to ignore the differences in behavior described by the labels it attaches to different persons. Second, labeling theory does not increase, and may well decrease, our ability to predict individual behavior. Third, its relevance to social policy is lessened by placing the blame for deviant behavior upon society rather than upon the individual.

By decriminalization of such deviant behavior as drug use, homosexuality and wife and child abuse, the state will only encourage the increase in such types of behavior. While it is not the business of the state to enforce any particular brand of morality, it has the duty to protect the young and the weak from exploitation. Thus while homosexuality between adults may well be legalized, this should not be extended to include homosexual acts between adults and males under age. The same principle applies to the punishment of wife and child abuse and of rapists.

109. Id., at 47.

110. Id., at 42 .

111. Id., at 43 .

112. Id.

113. Id., at 187-88. Cf. E. TAylor, The New Legality 28-52 (1967) for a discussion of the "Christian Approach to the Problem of Homosexuality." 
Fersch proposes an "instant cure" of both rape and homosexuality by declaring they are no longer to be considered as the acts of sick persons, nor as crimes.

A further element in the Christian response to the Therapeutic State is the separation of punishment and rehabilitation. Fersch again makes a similar point: "There is a complete separation of punishment and rehabilitation. The first is mandatory and brief, and offered in special settings, chosen from various categories of punishment. The second is voluntary, genuinely offered, and the individual is free to accept or reject the offer."114

Finally, I believe that the Christian view alone can solve the secular humanist dilemma of punishment versus treatment, a dilemma from which not even Fersch seems able to escape from his well-meant efforts to "rethink" our present methods of crime control. If neither the punitive nor the therapeutic ideologies or models of crime control can provide us with a valid basis for public policy on the handling of criminals, it seems we are left either with the "Rethinking Method" or the biblical-reformational approach.

The "Rethinking" advocates of crime control fail to address the crucial question: How can both requirements be combined so that both the individual criminal and his society each make proper expiation and restitution for the crime committed? The Christian answer is to arrange for society also to help expiate the wrong done in the method of punishing the criminal, and to admit its own share of responsibility. The idea of both expiation and responsibility must be cultivated afresh so that every member of society recovers a sense of his or her own personal responsibility for the original sinfulness of society, the sinfulness of the criminal, and his or her own need to make expiation for the wrongdoing. This must be done in such a way that it does not foster a spirit of self-righteousness, nor a sadistic enjoyment of cruel punishment, but in such a way that in the sacrifice of time and money which the punishment imposes upon society as well as upon the criminal, society will be reminded of its own guilt. This means that in practice the Christian will agree with those modern penologists who press for the individualizing and humanizing of the administration of criminal justice and the penal law, while in theory he or she will support the adherents of the theory of expiation and just retribution for wrongdoing. The guilty person must expiate his crime: this means that all who are guilty must offer expiation-society as a whole by means of the taxes imposed to support the costs of maintaining prisons and rehabilitation centers, police, prison guards, lawyers and judges.

Included within the proposed Christian Penal Law policy and program would be:

A. Creative Restitution. Society must expiate its share in the crime and especially its numerous sins of omission, by arranging for the financial compensation of any innocent victim of crime, or of his or her relatives if he or she has been murdered. Our courts must make it obligatory to provide adequate restitution

114. FersCh, supra note 58, at 44. 
directly to the victim out of public tax funds levied upon the community and the state in which the crime took place or wherever the criminal made his home. This would remind the criminal's home community of its share of responsibility. ${ }^{115}$ In addition, the convicted criminal must also be made to help make reparation. This can best be done by providing the offender with an opportunity to earn money, preferably on probation rather than in prison. Probation has the great advantage that the probationer, being at liberty, has a better opportunity to make payments toward the support of his own family and toward making restitution to his victim.

B. Much Greater Use of Probation. For many offenders probation is likely to be at least as effective in preventing recidivism as an institutional sentence. Prisons should be kept as places of incapacitation for the most hardened criminals and recidivists. The Bible never made use of prisons until after Israel returned from captivity in Babylon and it was thus a heathen importation. ${ }^{116}$

It is not generally realized that prisons appear in biblical law only as places of custody, pending trial, and never as places of permanent confinement. Rushdoony points out that the methods of dealing with criminals in Old Testament society were threefold:

First, capital punishment was required for capital offenses, and for incorrigible criminals. Second, for all other offenses, restitution was the law; where an order of law had been violated, restoration was the basic function of the courts. Emphatically, in Biblical law the goal is not punishment but restoration, not the infliction of certain penalties on criminals but the restoration of godly order. . . Third, where criminals were unable to make restitution, bond-service was mandatory in order to work out the required restitution. . . .

Western civilization began as an unhappy compromise between the Biblical standard of restitution and a Graeco-Roman and pagan criminology . . . . which leaned heavily towards punishment. The prison thus had a place in Christendom, as an ugly, bastard compromise. It was not only a place of custody, but also a place for torture and punishment; a place to hold men for ransom or for elimination from a threatening position in the state. The prison was an accepted but illegitimate part of the social order. ${ }^{117}$

The idea of incarcerating men and women in prison for ten to twenty years as a method of "reforming" them would never have occurred to the men of the Bible. They did not have to worry about imprisoning murderers, as these were executed as soon as their guilt had been established. By abolishing God's penalty for premeditated murder, secular humanism has brought upon American society the problem and evil of imprisonment.

Nowhere is this evil more apparent than in the case of young offenders. The present system of putting first and young offenders into the same type of prison as hardened offenders, which still prevails in most of the United States, only serves to turn such young people into professional criminals. The criminal subculture of the

115. Various methods of restitution are discussed by S. Schafer in Restitution to Victims of Crime (1960).

116. R. Rushdoony, The Institutes of Biblical Law $514-22$ (1973).

117. Id., at 515. Cf. Berns supra note 29, at 43-65, "The Invention of the Penitentiary." 
prison tends to reinforce the worst characteristics of the young offender. Under parole or probation, the young offender can be re-integrated into sets of social relationships where criminality as a way of life is truly taboo. Let our church congregations volunteer to take care of one or two offenders, providing them with Christian primary and peer groups in which they can be helped to overcome the temptation to commit crime.

C. Much Greater Use of Fines. Other much needed reforms of our present criminal justice system should include a much greater use of fines and restoring a hierarchy of penalties. Hammond's study in England ${ }^{118}$ found that fines and discharges are much more effective than either probation or imprisonment for first offenders and recidivists of all age groups. Fines are most likely to be imposed for embezzlement, fraud, larceny, lottery (and other gambling violations), loitering, and other disorderly conduct. Providing he has the means to pay, the fine affords to the person convicted of a felony or misdemeanor the opportunity to choose the nature of the impact of the penalty upon his life. Max Gruhut suggests that in the case of poor offenders fines be assessed according to the offenders' resources rather than the gravity of the offense, and that installment payments be allowed. ${ }^{19}$

D. Restoring a Proper Hierarchy of Penalties. In the light of the biblical doctrine of expiation for wrongdoing, the penalties for crime must bear some relationship to the degree of the seriousness of the crime committed. The principle of expiation prevents excessive severity on the one hand, and extreme leniency on the other in the administration of criminal justice. If deterrence becomes the sole guiding rule in this matter, then great injustices may result, since any punishment can be imposed for any crime committed, provided it is calculated to deter others. Judges, guided solely by their own emotional reaction to the offender at the bar, may impose light punishments for serious crimes, such as murders; and the majesty of the law will be brought into disrepute. Long Longford, an English Roman Catholic layman and a former attorney general in the British Government, points out that the person who has committed a greater crime and been found guilty of more wickedness should pay a heavier penalty than the smaller or less-wicked offender and that this idea rests on the concept of merit or demerit. ${ }^{120}$

E. Tempering Justice with Mercy. Finally, the Christian response to the Therapeutic State requires that our judges exercise their God-ordained ministry of justice with mercy. It is mercy not treatment that the Lord requires of us as the prophet Micah well expressed: "He has told you, O man, what is good; And what does the Lord require of you; But to do justice, to love mercy, and to walk humbly with your God." ${ }^{121}$ If crime is only a sickness, how can we show mercy toward it? As C.

118. The Sentence of the Court; A Handbook for Sentences (1969).

119. M. Gruhut, Penal. Reform (1948).

120. Lord Longford, supra note 105; A. Ewing also has some useful things to say in ThE Morality of Punishment (1952).

121. Micah 6:8. 
S. Lewis pointed out: "The essential act of mercy was to pardon; and pardon in its very essence involves the recognition of guilt and ill-desert in the recipient. If crime is only a disease which needs cure, it cannot be pardoned. How can you pardon a man for having a gumboil or a club foot?"122

As I have already pointed out, the abolition of the doctrines of individual responsibility and of just expiation for wrongdoing really amounts to the depersonalization of the criminal. For the contrast between intentional, rational, and deliberate actions, on the one hand, and such aberrations as accident, mistake, automatism, and insanity on the other, lies at the very root of our Christian concept of what it means to be a person rather than a mere object. Such a view of men and women as persons created not in the image of society, as secular humanists suppose, but in the image of Almighty God has in fact been derived from the biblical view of man and woman; and it will be a tragic day for American, British and Canadian criminal jurisprudence when it is lost, for then justice as well as mercy will have perished from our societies. May the living God of the Bible preserve us from such a fate as that now being suffered by the peoples of the Communist lands of Russia, Red China, Cambodia and Eastern Europe, where the Therapeutic Power-State has triumphed over the Christian Law-State and medicine has replaced justice as the basis of their criminal justice systems. ${ }^{123}$

122. Lewis, supra note 26, at 11 .

123. S. Block and P. Reddaway, Psychiatric Terror How Soviet Psychiatry Is Used to Suppress Dissent (1977). The authors fully document the history of the Soviet government's misuse of psychiatrists and mental hospitals to suppress political dissent and show in detail how the Soviet Union's whole mental health apparatus has been used by the government in its political police work until the distinction between psychiatrist and interrogator, diagnosis and sentence, mental hospital and prison, has all but disappeared for many of its victims. 